\title{
Retraction Note: An evaluation of the potential consequences of drilling titanium and tantalum implants during surgery - a pilot study
}

Paweł Skowronek ${ }^{1}$, Paweł Olszewski ${ }^{1}$, Wojciech Święszkowski ${ }^{2}$, Marcin Sibiński ${ }^{3}$, Marek Synder ${ }^{3}$ and Michał Polguj ${ }^{4^{*}}$

\section{Retraction Note: BMC Musculoskelet Disord https://doi.org/10.1186/s12891-017-1784-x}

The authors have retracted this article [1] because it constitutes redundant publication [2]. The authors signed the licensing agreement for publication in HIP International before submitting the manuscript to BMC Musculoskeletal Disorders. All authors agree to this retraction.

\footnotetext{
Author details

'Clinic of Orthopedic and Traumatology, Regional Hospital and Kochanowski Medical University, Kielce, Poland. ${ }^{2}$ Faculty of Materials Science and Engineering, Warsaw University of Technology, Warsaw, Poland. ${ }^{3}$ Clinic of Orthopedics and Pediatric Orthopedics, Medical University of Lodz, Lodz, Poland. ${ }^{4}$ Department of Angiology, Medical University of Łódź, ul.

Narutowicza 60, 90-136 Łódź, Poland.
}

Published online: 24 October 2019

\section{References}

1. Skowronek P, Olszewski P, Święszkowski W, Sibiński M, Synder M, Polguj M. An evaluation of the potential consequences of drilling titanium and tantalum implants during surgery - a pilot study. BMC Musculoskelet Disord. 2017;18(1):426 https://doi.org/10.1186/s12891-017-1784-X.

2. Skowronek P, Olszewski P, Święszkowski W, Synder M, Sibiński M, Mazek J. Unrecoverable bi-products of drilling titanium alloy and tantalum metal implants: a pilot study. HIP Int. 2018;28(5):531-4 https://doi.org/10.1177/ 1120700018760306.

\footnotetext{
*Correspondence: michal.polguj@umed.lodz.pl

${ }^{4}$ Department of Angiology, Medical University of Łódź, ul. Narutowicza 60,

90-136 Łódź, Poland

Full list of author information is available at the end of the article
}

(c) The Author(s). 2019 Open Access This article is distributed under the terms of the Creative Commons Attribution 4.0 International License (http://creativecommons.org/licenses/by/4.0/), which permits unrestricted use, distribution, and reproduction in any medium, provided you give appropriate credit to the original author(s) and the source, provide a link to the Creative Commons license, and indicate if changes were made. The Creative Commons Public Domain Dedication waiver (http://creativecommons.org/publicdomain/zero/1.0/) applies to the data made available in this article, unless otherwise stated. 